\title{
Comparison of protection from homologous cell-free vs cell-associated SIV challenge afforded by inactivated whole SIV vaccines
}

\begin{abstract}
Heeney JL, de Vries P, Dubbes R, Koornstra W, Niphuis H, ten Haaft P, Boes J, Dings MEM, Morein B, Osterhaus ADME. Comparison of protection from homologous cell-free vs cell-associated SIV challenge afforded by inactivated whole SIV vaccines. J Med Primatol 1992:21:

$126-130$.

This study attempted to determine if SIV vaccines could protect against challenge with peripheral blood mononuclear cells (PBMCs) from an SIV infected rhesus monkey. Mature Macaca mulatta were vaccinated four times with formalin inactivated SIV $_{\text {mac } 32 \mathrm{H}}$ administered in MDP adjuvant $(\mathrm{n}=8)$ or $\mathrm{SIV}_{\text {mac32H }}$ ISCOM vaccine $(\mathrm{n}=8)$. Controls included animals vaccinated with measles virus in MDP adjuvant $(n=4)$ or ISCOM $(n=$ 4) preparations. Of each group, half were challenged intravenously (IV) with ten $\mathrm{MID}_{50}$ of the cell-free $\operatorname{SIV}_{\text {mac32H }}$ (11-88) SIV stock and half were challenged with ten $\mathrm{MID}_{50}$ of PBMCs from the SIV $\mathrm{mac} 32 \mathrm{H}_{\text {infected }}$ macaque 1XC. All SIV vaccinated animals challenged with the 11-88 cell free stock of SIV $_{\text {mac32H }}$ were protected, whereas only half of the SIV vaccinated monkeys receiving the same infectious dose of the $1 \mathrm{XC}$ cell stock were protected.
\end{abstract}

\section{J.L. Heeney, ${ }^{1}$ P. de Vries, ${ }^{2}$ \\ R. Dubbes, ${ }^{1}$ W. Koornstra, ${ }^{1}$ \\ H. Niphuis, ${ }^{1}$ P. ten Haaft, ${ }^{1}$ \\ J. Boes, ${ }^{2}$ M.E.M. Dings, ${ }^{2}$ \\ B. Morein, ${ }^{3}$ A.D.M.E. Osterhaus $^{2}$}

'Laboratory of Viral Pathogenesis, Institute of Applied Radiobiology and Immunology TNO, Rijswijk, The Netherlands; ${ }^{2}$ Laboratory of Immunobiology, RIVM, Bilthoven, The Netherlands; ${ }^{3}$ Biomedical Center, Uppsala, Sweden

Key words: lentivirus - vaccine - cellassociated challenge - ISCOM - MDP protective immunity

Jonathan Luke Heeney, Institute of Applied Radiobiology and Immunology TNO, P.O. Box 5815, 2280 HV Rijswijk, The Netherlands

Accepted for publication February 17, 1992

\section{Introduction}

The significance and importance of the SIV model in macaques for AIDS pathogenesis and vaccine development research has been well documented $[3,4,6,15]$. Whole inactivated SIV vaccines or SIV envelope-enriched vaccines have been demonstrated to protect macaques against low-dose intravenous challenge with homologous SIV strains propagated in culture on human $\mathrm{T}$ cells $[2,5,6$, $11,12,13]$. Protection of macaques from $\operatorname{SIV}_{\mathrm{sm}}$ or HIV-2 infection has been demonstrated by passive immunization [14] suggesting that protective immunity is humorally mediated. Considerable controversy has developed concerning the validity of SIV vaccine results since a study reported the problem of contaminating cell components from the same human $\mathrm{T}$-cell line used to produce the vaccine as well as the virus challenge stock [16]. However, recent publication of SIV vaccine protection with recombinant antigens supports the premise that vaccine protection in this model is SIV antigen specific [8]. Realistic challenge of such vaccines by either cell-associated intravenous or mucosal challenge from virus produced from the host species are critical tests for true lentivirus development [15]. Evi- dence of protection from monkey propagated virus or virus infected macaque PBMCs may aid in clarifying this controversy. This study set out to determine if whole inactivated SIV vaccines capable of protecting from cell-free IV challenge could also protect against an infected cell challenge from an SIV-infected macaque with AIDS.

The importance of such vaccine efficacy studies with infected cells propagated in vivo in homologous species is clearly very relevant and of high priority for HIV vaccine development. This experiment revealed that the vaccinated group challenged intravenously with cells from an infected monkey with AIDS was protected from infection. These results are the first to demonstrate that vaccine protection against cell associated challenge is possible.

\section{Materials and methods}

Animals and vaccine challenge stocks

Mature Macaca mulatta were pre-bled for routine hematology and establishment of base-line values. All animals were SIV, STLV, and SRV free out- 
bred macaques of northern India origin bred in captivity at TNO.

Vaccine Challenge Stocks consisted of the

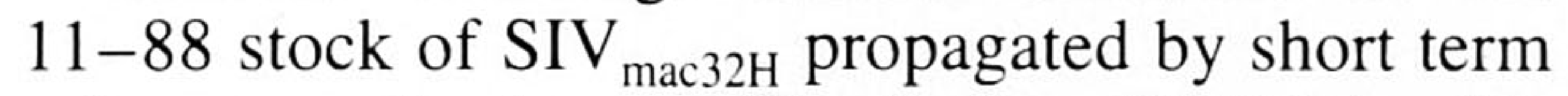
culture on the human T-cell line C8166 by $\mathrm{M}$. Cranage and colleagues (Center for Applied Microbiological Research, Salisbury, U.K.), aliquoted and titrated in vivo as part of an EC collaborative effort. A dose of $10 \mathrm{MID}_{50}$ of this stock was administered IV as a single challenge for group A. An intravenous dose of $50 \mathrm{MID}_{50}$ of this stock was administered to a rhesus macaque (1XC) from which a large stock of PBMCs was prepared and titrated in vivo (H. Niphuis, ITRI-TNO, personal communication). A dose of 20,000 PBMCs was found to be equivalent to approximately one $\mathrm{MID}_{50}$. Hence, the challenge dose of $2 \times 10^{5} 1 \mathrm{XC}$ PBMCs was used to give an equivalent ten MID $_{50}$ challenge to group B.

\section{Vaccines}

SIV $_{\text {mac } 32 \mathrm{H}}$ was derived from culture supernatant of infected C8166 cells and purified by ultracentrifugation and gel exclusion chromatography. Material was provided by programme EVA of the European Sponsored AIDS programme.

The inactivated whole virus vaccine was prepared by the addition of $0.8 \%$ formaldehyde to SIV $_{\text {mac32H }}$ and subsequent mixing with the adjuvant muramyl dipeptide (MDP, Sigma). The ISCOM vaccine consisted of a mixture of several components: (1) a whole SIV ISCOM preparation prepared from the same purified virus according to standard methods [10]; (2) lectin-purified gp130 incorporated into ISCOMs by the acidic method or covalently coupled to preformed ISCOM matrix; and (3) soluble p27, not incorporated during preparation of whole SIV ISCOM. The inactivated whole SIV vaccine and the SIV ISCOM vaccine were prepared in such a way that they contained approximately the same amounts of gp130 and p27. The inactivated whole MV and MV ISCOM preparations, which were used for immunizing the control monkeys have been described previously [10]. All monkeys were vaccinated intramuscularly four times at $0,4,10$, and 16 weeks (group A) or 0,4 , 10 , and 22 weeks (group B).

\section{Serological analyses}

Western blot analysis (WB) was performed by immunoblotting of SDS-PAGE separated SIVinfected cell proteins to nitrocellulose with antibody detection of antibodies to SIV using peroxidase conjugated antimonkey IgG as previously described [17]. SIV-specific monoclonal antibodies (KK5, 8,
11 , and 33) were used to confirm the specificity of the antigens detected as previously described [9].

KK-5 inhibition enzyme linked immunosorbent assay (ELISA) was performed using detergent dis-

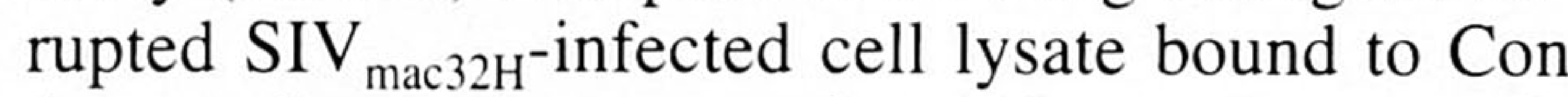
A coated on polystyrene plates. Serum from vaccinated and challenged monkeys was competed for binding of $\mathrm{KK}-5$, a monoclonal antibody that recognizes a conformation dependent virus neutralization epitope of $\mathrm{SIV}_{\text {mac32H }}$.

\section{Antigen detection in plasma}

Serum and plasma samples were used to determine the presence or absence of viral antigen postchallenge by antigen capture analysis. Antigen capture was performed using the Coulter SIV core antigen detection kit according to the guidelines listed by the manufacturer (Coulter Corp., Hialeah, FL, U.S.A.).

\section{Virus isolation}

Ficol separated PBMCs were enumerated, and duplicate samples of $5 \times 10^{5}$ PBMCs in $0.5 \mathrm{ml}$ (RPMI, 10\% FCS) were added to $0.5 \mathrm{ml}$ media contain $2.5 \times 10^{5} \mathrm{C} 8166$ cells and incubated at $37^{\circ} \mathrm{C}$ for three weeks. Medium was refreshed two times per week and supernatant samples were retained for antigen capture analysis. Samples were confirmed negative or positive by reanalysis on cocultivated samples one week later. Samples were taken over a period of three weeks. Antigen capture values with an absorbance greater than or equal to the cut off value were considered positive for SIV antigen. All positive results were retested in duplicate for confirmation.

\section{Results}

\section{Serological analyses}

Western blots of group A (Fig. 1) and group B (Fig. 2) demonstrated a strong antibody response to p27 present in the vaccine preparations based on samples taken on the day of challenge. In both groups $\mathrm{A}$ and $\mathrm{B}$, a stronger reactivity to gp130 was noted in animals vaccinated with ISCOMs than in animals vaccinated with formalin inactivated, MDP adjuvanted vaccine. ELISAs based on competive binding with the conformation dependent neutralizing antibody KK5 confirming the observation that SIV ISCOM induced higher antibody titers than the inactivated whole SIV preparation. SIV KK5 inhibition titers were not observed in measles vaccinated controls. Upon challenge all control animals developed SIV-specific antibody titers beginning 


\section{Heeney et al.}

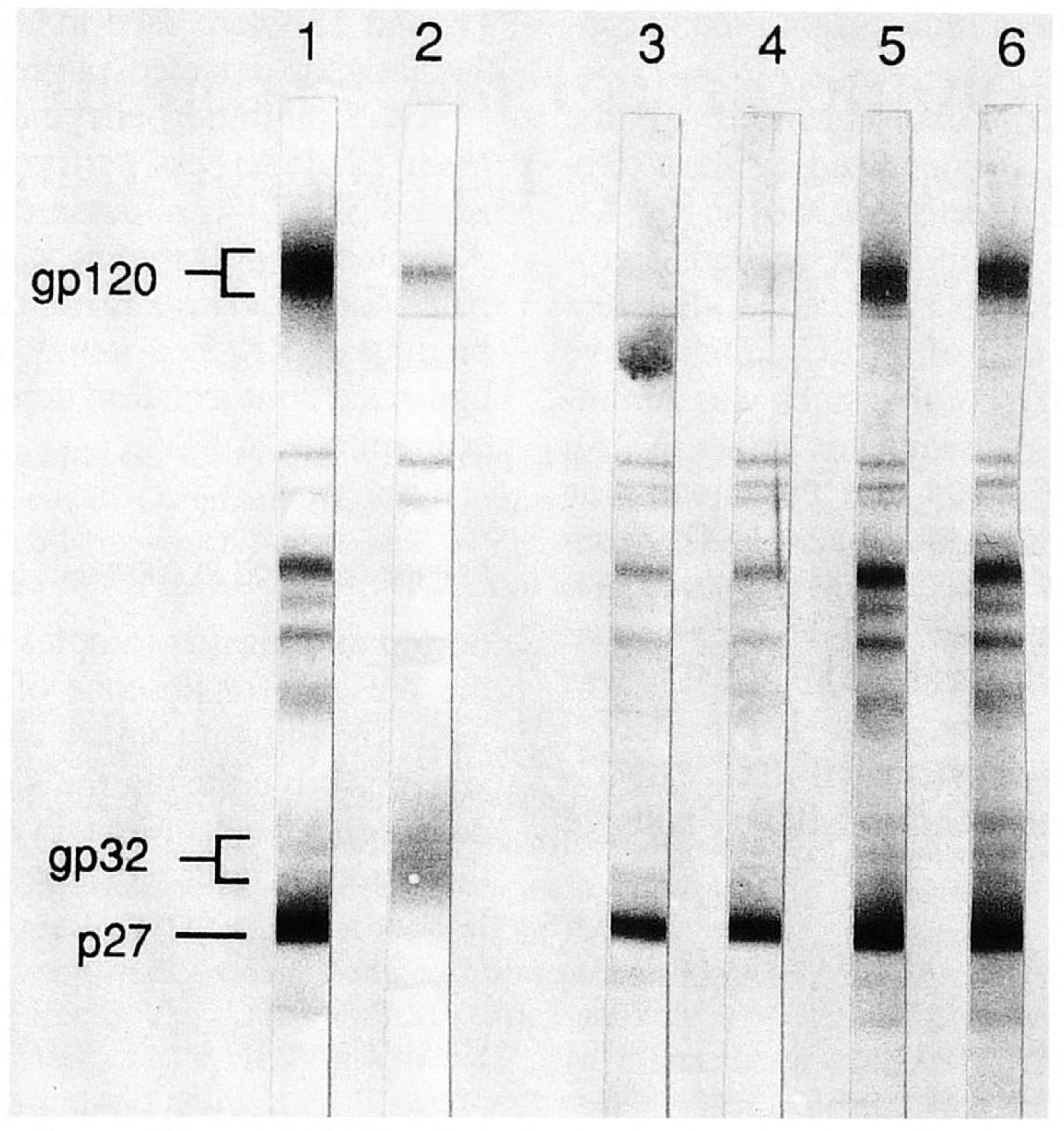

Fig. 1. Western blot analysis of four group A rhesus monkey plasma samples at day of challenge. The antigen used was a lysate of $\mathrm{SIV}_{\mathrm{mac} 32 \mathrm{H}}$ infected C8166 cells. Lane 1 shows the reactivity of monoclonal antibodies KK8 and KK33 with specificity for gp 160/120 and p27, respectively. Lane 2 shows the reactivity of monoclonal antibody KK16, specific for gp 160/32. Lanes 3 to 6 show antibody responses to monkey 4094, 1XD (both SIV-MDP vaccinated), 8656, and 1XB (both SIV ISCOM vaccinated).

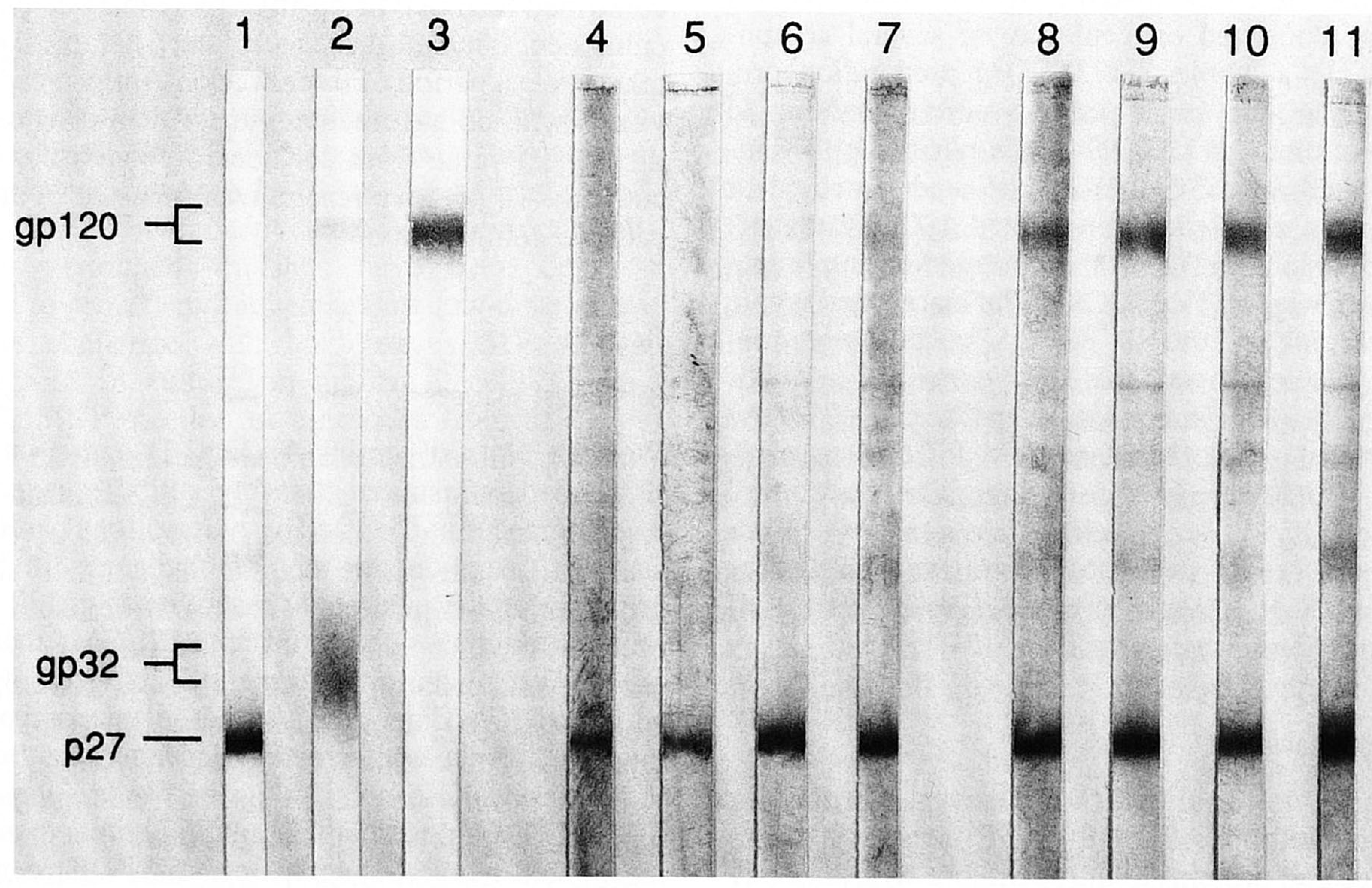

Fig. 2. Western blot analysis of eight group B rhesus monkey plasmas at day of challenge. Lanes 1 to 3 show the reactivity of monoclonal antibodies KK33, KK16, and KK8, respectively. Lanes 4 to 7 show antibody responses of monkey 8645, KP, 8649, IIM (all four SIV-MDP vaccinated), 8730, 4097, 8653, and 8666 (all four SIV ISCOM vaccinated). 
Table I. Vaccination/challenge schedule and postchallenge status

\begin{tabular}{|c|c|c|c|c|c|c|}
\hline \multirow[b]{2}{*}{ Vaccine } & \multirow[b]{2}{*}{ Monkey } & \multirow{2}{*}{$\begin{array}{l}\text { Vaccine schedule } \\
\text { (months) }\end{array}$} & \multirow{2}{*}{$\begin{array}{l}\text { Challenge }^{d} \\
10 \text { MID }_{50}\end{array}$} & \multicolumn{2}{|c|}{ Weeks positive } & \multirow[b]{2}{*}{ Status } \\
\hline & & & & $\mathrm{PI} . \mathrm{Ag}^{\mathrm{a}}$ & V.I. ${ }^{b}$ & \\
\hline \multirow[t]{4}{*}{ MV ISCOM } & 8789 & $0,1,2,4$ & cell-free & 2,8 & 4,9 & infected \\
\hline & 8791 & $0,1,2,4$ & cell-free & 2 & 4,9 & infected \\
\hline & 8672 & $0,1,2,5$ & cell-associated & 2,4 & 4,9 & infected \\
\hline & 8679 & $0,1,2,5$ & cell-associated & 2 & 4,9 & infected \\
\hline \multirow[t]{4}{*}{ MV MDP } & 4060 & $0,1,2,4$ & cell-free & 2 & 4,9 & infected \\
\hline & $1 \mathrm{YH}$ & $0,1,2,4$ & cell-free & 2 & 4,9 & infected \\
\hline & $2 \mathrm{CA}$ & $0,1,2,5$ & cell-associated & 2 & 4,9 & infected \\
\hline & $1 \mathrm{JH}$ & $0,1,2,5$ & cell-associated & 2 & 4,9 & infected \\
\hline \multirow[t]{8}{*}{ SIV ISCOM } & 4053 & $0,1,2,4$ & cell-free & neg. & neg. & protected \\
\hline & $1 X V$ & $0,1,2,4$ & cell-free & neg. & neg. & protected \\
\hline & $1 \mathrm{JB}$ & $0,1,2,4$ & cell-free & neg. & neg. & protected \\
\hline & $8656^{c}$ & $0,1,2,4$ & cell-free & & & \\
\hline & 4097 & $0,1,2,5$ & cell-associated & neg. & 4,9 & infected \\
\hline & 8653 & $0,1,2,5$ & cell-associated & neg. & 4,9 & infected \\
\hline & 8668 & $0,1,2,5$ & cell-associated & neg. & neg. & protected \\
\hline & 8730 & $0,1,2,5$ & cell-associated & neg. & neg. & protected \\
\hline \multirow[t]{8}{*}{ SIV-MDP } & 4083 & $0,1,2,4$ & cell-free & neg. & neg. & protected \\
\hline & 4094 & $0,1,2,4$ & cell-free & neg. & neg. & protected \\
\hline & $1 X D$ & $0,1,2,4$ & cell-free & neg. & neg. & protected \\
\hline & 3B & $0,1,2,4$ & cell-free & neg. & neg. & protected \\
\hline & KP & $0,1,2,5$ & cell-associated & neg. & 4,9 & infected \\
\hline & $1 \mathrm{M}$ & $0,1,2,5$ & cell-associated & neg. & 4,9 & infected \\
\hline & 8645 & $0,1,2,5$ & cell-associated & neg. & neg. & protected \\
\hline & 8649 & $0,1,2,5$ & cell-associated & neg. & neg. & protected \\
\hline
\end{tabular}

a Plasma antigen, weeks positive.

bVirus isolation, weeks positive.

${ }^{c}$ Died during recovery from anaesthesia at day of challenge (not included).

${ }^{\mathrm{d}}$ Group $\mathrm{A}=$ cell-free, group $\mathrm{B}=$ cell-associated challenge .

one month postchallenge when challenged with either cell-free SIV (group A) or cell associated SIV (group B) challenge (Table I).

\section{Virus isolation}

Macaques vaccinated with either formalin inactivated SIV in MDP adjuvant or SIV ISCOMs challenged with ten $\mathrm{MID}_{50}$ of cell-free C8166 propagated virus stock (group A) were all protected (seven out of seven) based on repeated negative virus isolation and negative plasma antigen on day 14 (one of the original eight animals died incidentally on the day of challenge). Measles vaccinated control monkeys became positive for SIV antigen at day 14, and virus isolation was possible from PBMCs at all subsequent time points (see Table I).

SIV vaccinated macaques challenged with ten MID $_{50}\left(200,000\right.$ cells) PBMCs from an SIV $_{\text {mac32H }}$ infected macaque were not uniformly protected. Measles virus vaccinated controls became plasma SIV antigen positive at day 14 and positive for SIV by virus isolation at subsequent time points. SIV vaccinated animals were negative for plasma antigen on day 14, but in both formalin inactivated/ MDP and ISCOM SIV vaccine groups (two out of four), animals in each group were virus isolation positive (Table I). To date four out of eight SIV vaccinated animals challenged with SIV infected macaque PBMCs remain protected based on re- peated negative virus isolation attempts. In addition, protected animals were noted to have decreasing titers, while infected animals developed rising SIV antibody titers postchallenge.

\section{Discussion}

Vaccine protection (active) of nonhuman primates from lentivirus infection has been achieved in chimpanzees vaccinated with recombinant HIV-1 env gp120 [1] or with a combination based on boosts with V3 specific peptides [7], and in macaques with both whole virus vaccines $[5,11]$ and enriched virus glycoprotein $[12,13]$. Protection in the macaque model with recombinant vaccinia priming $\left(\mathrm{SIV}_{\text {mnegp 160 }}\right)$ followed by recombinant baculovirus expressed gp160 resulted in protection of pig-tailed macaques from biologically cloned, human T-cell propagated SIV $_{\text {mne }}$ challenge [8]. However, to date these results have not been reproducible in the SIV $_{\text {mac }}$ system (A. Schultz, NIH, personal communication).

Whole virus vaccines of $\operatorname{SIV}_{\text {DeltaB670 }}$ or $\mathrm{SIV}_{\operatorname{mac} 251(32 \mathrm{H})}$ inactivated with formalin have been demonstrated to give protection against homologous and heterologous challenge. These results have been achieved using cell-free SIV of various strains propagated on human $\mathrm{T}$-cell lines. This study set out to determine if protection could be achieved by the same dose of infected PBMCs har- 
vested from a monkey (1XC) 11 months after infection with the same SIV strain used to produce the whole virus vaccines.

Our results demonstrate that two different whole vaccine preparations that are able to protect against cell-free challenge are also able to elicit protection in $50 \%$ of animals challenged intravenously with PBMCs from a macaque infected with homologous virus 11 months earlier. The reasons for achieving only partial protection may be explained by at least two possibilities. First, cell associated virus may result in an intracellular persistent infection resulting in infection from donor cells to host cells without sufficient opportunity for extracellular neutralization. The second possibility may be due to the genetic diversity of the challenge stock obtained from an animal 11 months postinfection with AIDS. The in vivo period of propagation of $\mathrm{SIV}_{\text {mac } 32 \mathrm{H}}$ may have permitted variant virus to evolve that is capable of escaping neutralizing immunity induced by the vaccine strain.

These results demonstrate the feasibility of developing a practical efficacious vaccine for HIV protection in man. The mechanisms by which cellassociated protection or failure are achieved must be elicited for the development of vaccine strategies capable of providing complete protection against cell associated challenge.

\section{Acknowledgments}

The authors thank Martin Cranage and coworkers for the generous supply of the 11-88 pool of the $\mathrm{SIV}_{\operatorname{mac} 251}$ derived challenge stock called SIV $_{\text {mac } 32 \mathrm{H}}$. This work was performed in concert with a European Community sponsored Concerted Action on macaque models for AIDS (G. Hunsmann). This work was in part supported by a Dutch Health Organization grant (A. Osterhaus, RIVM) and a European community grant for the Centralized Facility for AIDS Research at ITRI-TNO. Many of the reagents for this program were supplied by the EC EVA program. We are indebted to Mrs. Mea van der Sman for her expertise and rapid preparation of this manuscript. Corrie Wimmers performed the essential tasks of organization and logistics with the cooperation of the staff of the Biotechnology department.

\section{References}

1. Berman PW, Gregory TJ, Riddle L, Nakamura GR, Champe MA, Porter JP, Wurm FM, Hershberg RD, Cobb EK, EIchberg JW: Protection of chimpanzees from infection by HIV-1 after vaccination with recombinant glycoprotein gp120 but not gp160. Nature 345:6276, 622-625, 1990

2. Carlson JR, McGraw TP, Keddie E, Yee Jl, Rosenthal A, Langlois AJ, Dickover R, Donovan R, Luciw PA, Jennings MB, Gardner M: Vaccine protection of rhesus macaques against simian immunodeficiency virus infection. AIDS Res Hum Retroviruses 6, 11, 1239-1246, 1990.

3. Chakrabarti L, Guyader M, Alizon M, Daniel MD, Desrosiers RC, Tiollais P, Sonigo P: Sequence of simian immunodeficiency virus from macaque and its relationship to other human and simian retroviruses. Nature 328, 6130, 543-547, 1987.

4. Daniel MD, Desrosiers RC, Letvin NL, King NW, Schmidt DK, Sehgal P, Hunt RD: Simian models for AIDS. Cancer Detect Prev Suppl 1:501-7, 1987.

5. Desrosiers RC, Wyand MS, Kodama T, Ringler DJ, Arthur LO, Sehgal PK, Letvin NL, King NW, DANIEL MD: Vaccine protection against simian immunodeficiency virus infection. Proc Natl Acad Sci USA 86, 16, 6353-6357, 1989.

6. Gardner MB: Vaccination against SIV infection and disease. AIDS Res Hum Retroviruses 6, 7, 835-846, 1990.

7. Girard M, Kieny MP, Pinter A, Barre-Sinoussi F, Nara P, Kolbe H, Kusumi K, Chaput A, Reinhart T, Muchmore E, Ronco J, Kaczorek M, Gomard E, Gluckman J-C, Fultz PN: Immunization of chimpanzees confers protection against challenge with human immunodeficiency virus. Proc Natl Acad Sci USA 88, 2, $542-546,1991$

8. Hu S-L, Abrams K, Barber GN, Moran P, Zarling JM, Langlois AJ, Kuller LR, Morton WR, BenVENISTE RE: Protection of macaques against SIV infection by subunit vaccines of SIV envelope glycoprotein gp160. Science 255:456-459, 1992.

9. Kent Ka, Gritz L, Stallard G, Cranage MP, Collignon C, Thiriart, C, Corcoran T, Silvera P, Stott EJ: Production of monoclonal antibodies to simian immunodeficiency virus envelope glycoproteins. AIDS 5:829-836, 1991 .

10. Morein B, Sundquist B, Hoglund S, Daisgaard K, Osterhaus A: ISCOM, a novel structure for antigenic presentation of membrane proteins from enveloped viruses. Nature 308:457-459, 1984.

11. Murphey-Corb M, Martin LN, Davison-Fairburn B, Montelaro RC, Miller M, West M, Ohkawa S, Baskin GB, Zhang Jy, Putney SD, Allison AC, EPSTEIN DA: A formalin-inactivated whole SIV vaccine confers protection in macaques. Science 246, 4935, 1293-1297, 1989.

12. Murphey-Corb M, Martin LN, Davison-Fairburn B, Montelaro RC, Miller M, West M, Ohkawa S, Baskin GB, Zhang JY, Putney S, Allison AC, EPSTEIN DA: A formalin inactivated whole SIV vaccine and a glycoprotein-enriched subunit vaccine confers protection against experimental challenge with pathogenic live SIV in rhesus monkeys. Dev Biol Stand 72:273-285, 1990.

13. Murphey-Corb M, Montelaro RC, Miller Ma, West M, Martin LN, Davison-Fairburn B, OhKawa S, Baskin GB, Zhang JY, Miller GB, Allison AC, EPSTEIN DA: Efficacy of SIV/deltaB670 glycoproteinenriched and glycoprotein-depleted subunit vaccines in protecting against infection and disease in rhesus monkeys. AIDS 5, 6:655-662, 1991.

14. Putkonen P, Thornstensson R, Ghavamzadeh L, Albert J, Hild K, Biberfeld G, Norrby E: Prevention of HIV-2 and SIV $_{\text {sm }}$ infection by passive immunization in cynomolgus monkeys. Nature 352:436-438, 1991.

15. Sonigo P, Girard M, Dormont D: Design and trials of AIDS vaccines. Immunol Today 11(12):465-471, 1990.

16. Sтотт EJ: Anti-cell antibody in macaques (letter). Nature 353, 6343:393, 1991.

17. Zhang Jy, Martin LM, Watson EA, Montelaro RC, West M, Epstein L, Murphey-Corb M: Simian immunodeficiency virus Delta-induced immunodeficiency disease in rhesus monkeys: Relationship of antibody response and antigenemia. J Infect Dis 158: $1277-1286,1988$. 